\title{
Twenty-five Years of Botanical Progress
}

$\mathrm{T}$ HE Brooklyn Botanic Garden had the felicitous idea of marking the twenty-fifth anniversary of its foundation in part by the presentation and subsequent publication of a series of addresses dealing with progress in this period of time in different fields of botanical science. The series of addresses appears in vol, 4 of the Memoirs of the Garden (May 7, 1936), and will interest botanical readers everywhere.

The addresses were commendably brief, with the result that the most significant aspects in each field are usually thrown into prominent relief. Thus, Prof. C. E. Allen, dealing with cytology, after a brief reference to cytoplasmic structures, centrosomes and cell-wall, has a very penetrating analysis of the chief features of interest in chromosome studies in the twenty-five year period.

This pairs very well with Dr. Blakeslee's equally interesting review of the progress of genetics. Dr. Blakeslee finds that he is provided with about 0.7 seconds in which to discuss the twenty-five years work of each single geneticist, which produces the surmise that the so-called 'leaders of science' are rather 'pushed' than leading. "It is not the conspicuous spray which erodes the coastline of our continent but masses of water which surge forward with united front". Dr. Blakeslee regards us as passing, in 1910, from the Mendelism and $3: 1$ ratio period to that of "Brass Tacks-Genes and Chromosomes". The significance of three techniques are emphasized in this latter period; the aceto-carmine method which has enabled the rapid study of the nuclei of large numbers of specimens, the production of mutation by radiation treatment and the analysis of chromosomal structure permitted by the salivary glands of fly larvæ.

Dr. Blakeslee decides that the last twenty-five years have brought us again to the species problem, and appropriately enough a contribution follows by Dr. Elmer D. Merrill, director of the New York Botanical Garden, who deals most temperately and justly with the species problem as seen by the experienced taxonomist.

Many other points of view are discussed in this entertaining volume; virus diseases are passed in review, the progress of ecological investigation, of forest administration and research, etc. In short, it is made clear that in the last twenty-five years progress in botany has passed beyond the grasp of any one individual. Let us hope that the result will be to make us all as reasonable in our demands as specialists as Dr. Merrill, who concludes that it is neither necessary nor desirable that all botanists should master the field of systematic botany. "Yet it can be maintained as a general truth that the individual investigator, no matter what his field, who has a reasonable knowledge of the names and relationships of the organisms with which he deals, is a better equipped individual for productive work within his own field, and that the teacher of botany who has the same knowledge is a better teacher".

\section{Geology in Great Britain}

Pats ART 1 of the "Summary of Progress of the Geological Survey of Great Britain" for $1933^{1}$ contains the usual annual reports of the Geological Survey Board and of the director and gives particulars of routine work carried out during the year under review. As in the succeeding year, there was some slowing down of normal activities on account of the immense amount of additional work involved in preparation for the transfer of the collections to the new museum at South Kensington. Nevertheless, thirty-nine maps were issued, together with five memoirs, which, with one exception, have already been noticed in our columns (NATURE, 134, 782; 1934); the remaining one, the Merthyr Tydfil memoir?

The old Museum of Practical Geology in Jermyn Street closed its doors to the public at the end of 1933. Sir John Flett contributes an interesting outline of its history from its opening in the year of the Great Exhibition of 1851 (see also NATURE, $134,129 ; 1934)$.

Part $2^{2}$ contains a series of papers on subjects of special interest. M. Macgregor and J. Pringle discuss the Scottish Millstone Grit in relation to that of the Pennines. The freshwater fauna of the Lower Coal Measures of Lancashire is described and the range of variation of its constituents demonstrated by $W$. B. Wright. The corresponding fauna in West Yorkshire is dealt with by D. A. Wray and A. E. Trueman. A valuable synopsis of Coal Measure plants and their stratigraphical distribution is provided by R. Crookall. The results of a study of the Carboniferous rocks of Innimore Bay, Morvern, on the Sound of Mull, are recorded by M. Macgregor and W. Manson. The fossils of certain pebbles in the Peel Sandstones of the Isle of Man are shown by H. P. Lewis to be of Salopian age. W. Manson describes the Carboniferous and Old Red Sandstone strata passed through by a boring for water (340 ft. deep) at Stonefold Farm, Berwickshire, with petrographical notes by $\mathbf{J}$. Phemister. Sir John Flett continues his investigations of the teschenite-picrite sills of the Lothians with a study of a thomsonized inclusion from the Blackness sill.

Part 1 of the "Summary" for $1934^{3}$, in addition to the usual information, records the transfer of offices, library and collections from Jermyn Street to South Kensington. The opening of the new Museum in July 1935 was recorded, with an account of the centenary celebrations, in NATURE (136, 75; 1935). Despite the strenuous activity necessitated by the change-over, and the employment of the equivalent of about one third of the field staff in the preparation of exhibits, all the normal departments of the Survey's work were carried on without 